\title{
Effect of Giving Brown Sugar (Arenga Pinnata) Against the Endurance of Football Players in the Special School of Sportsman Gor Sudiang Makassar
} \author{
Taiyeb $^{3}$ \\ ${ }^{1}$ Nutrition Department, Faculty of Public Health, Hasanuddin University, Indonesia \\ ${ }^{2}$ Department of Occupational Safety and Health, Faculty of Public Health, Hasanuddin University, Indonesia \\ ${ }^{3}$ Biology Department, Faculty of Mathematics and Natural Sciences, Makassar State University (UNM), Indonesia
}

Surya Chahyadi Jufri ${ }^{1 *}$, Healthy Hidayanty ${ }^{1}$, Lalu Muhammad Saleh ${ }^{2}$, Citrakesumasari ${ }^{1}$, Abdul Salam ${ }^{1}$, Musyawwir

DOI: $10.36348 /$ jaspe.2020.v03i07.001 $\quad$ | Received: 25.06.2020 | Accepted: 03.07.2020 | Published: 08.07 .2020

*Corresponding author: Surya Chahyadi Jufri

\section{Abstract}

This study aims to look at the effect of giving palm sugar water to the endurance of V02Max, endurance of the abdominal muscles as well as the energy intake of football players in the special school of sportsman GOR (Sport Building) Sudiang Makassar. The research method used in this study was an experimental study with a Pre-Experimental research design. The research design model is a one-group pretest-posttest. From the results of determining the inclusion and exclusion criteria, the samples obtained in this study were 30 soccer athletes, because 5 samples took the PSM Makassar U16 selection. The results of the study consuming palm sugar water have an influence on energy intake after the intervention in the athlete's special soccer school athlete GOR Sudiang Makassar were the post-test score on day $8(\mathrm{p}=0.002)$ and post tets day $15(\mathrm{p}=0,000)$. Consuming palm sugar water has an effect on the endurance of V02Max after the intervention of soccer athletes in the special school of sportsman GOR Sudiang Makassar were the post-test score on day $8(\mathrm{p}=0,000)$ and post-day $15(\mathrm{p}=0,000)$. Consuming palm sugar water has an effect on the endurance of the abdominal muscles after an intervention in soccer athletes at the GOR Sudiang Makassar sportsman school were the post-test score on day $8(\mathrm{p}=0,000)$ and post-test day $15(\mathrm{p}=0,000)$.

Keywords: Endurance, Brown Sugar, Sportsman, Football.

Copyright @ 2020: This is an open-access article distributed under the terms of the Creative Commons Attribution license which permits unrestricted use, distribution, and reproduction in any medium for non-commercial use (NonCommercial, or CC-BY-NC) provided the original author and source are credited.

\section{INTRODUCTION}

Physical condition plays an important role in achieving a good achievement because the physical condition is the main basis for soccer athletes to be able to play well and win. Because to be able to play for $2 \mathrm{x}$ 45 minutes a soccer player must have good cardiovascular endurance (VO2Max) [1] what's more if in this game the results are balanced then the extra time will be done in this case the role of endurance or physical condition of an athlete is very influential to be able to win.

The fitness of Indonesian athletes is generally low, which in turn has an impact on performance that has not improved or even worse at all levels at regional, national, and international levels. This can be proved by the average value of V02Max national team players who are still in the range of $60 \mathrm{ml} / \mathrm{kg} / \mathrm{min}$ very far when compared with European players who are on average in the range of $70 \mathrm{ml} / \mathrm{kg} / \mathrm{min}$ [2].

Overcoming this problem several studies have been carried out including by conducting variations in the exercises carried out by [3]. Variation of training in the form of circuit training with the ball and ball feeling training methods for eight days but can only affect the basic skills of football, does not affect the endurance of V02Max.

Different things done by [4] in his research the researchers gave 15-minute running training to girls who were active in basketball extracurricular activities for two months with a break of three days or equal to twice a week, with 15-minute running exercises giving effect to V02Max endurance. as for the factors that affect endurance according [5, 6] namely gender, age, heredity/genetics, exercise / physical activity, intake of nutrients which means the food is eaten and drinks of an 
athlete as well as smoking habits, this affects the endurance of an athlete.

Different things in the study where the provision of food intake that contains carbohydrates, protein, and fat for eleven days in accordance with the total energy needs of athletes but does not affect the endurance of soccer athletes [7,8]. The provision of complex carbohydrates to athletes is much better than simple carbohydrates before doing sports because it can help improve the endurance of VO2Max athletes [9, 10].

In line with the research conducted by [11] were in his study comparing athletes who consumed wheat bread with complex carbohydrate content before doing sports better endurance compared with athletes who consumed white bread that has a simple carbohydrate content. Eating ambon 150 gr bananas 2 hours before doing a sport balke test can increase the endurance of V02Max [12].

This research is in line with [9] consuming drinks that contain carbohydrates or drinks that contain sugar can improve performance when exercising. Sari [13] in his research on soccer athletes in Samarinda found that drinking coffee can have an effect on muscle endurance before exercising theoretically caffeine is a major component of coffee that has an effect on human muscles, caffeine can improve muscle performance and inhibit muscle fatigue, but when compared with the provision of glucose before exercise, the effect of glucose on muscle power is far better than the provision of coffee before exercise [14] drinking coffee before exercising can have an effect on increasing V02Max endurance [15]. Giving dates juice before exercising can increase endurance V02Max [16].

Based on a description of what has been done by previous researchers in dealing with the endurance problem of soccer athletes. Researchers are interested in conducting research by providing palm sugar water on endurance because it is based on theory when exercising with a heavy intensity like soccer, carbohydrate is the source main energy and still a lack of people doing research on the provision of palm sugar on endurance, besides palm sugar has other mineral content that is very influential for the body, including ash, calcium, phosphorus, iron, water, sodium, copper, zinc riboflavin, niacin according to [17].

Here are some studies on the provision of brown sugar on endurance according [18] in a study that has done the administration of brown sugar with a dose of 21 grams in $250 \mathrm{ml}$ of water carried out 3 times a week and for 6 weeks on athletes can increase endurance athletes when doing sports.

According to [19] in his research giving athletes one week of brown sugar had no effect on endurance but brown sugar was able to suppress levels of lactic acid in the body. Research result Samudera \& Ashadi [20] said that giving $50 \mathrm{ml}$ of brown sugar water dissolved in $150 \mathrm{ml}$ water, given to athletes for one week while exercising can reduce athlete hydration.

Consuming 50 grams of brown sugar for 12 days before doing sports activities can increase endurance athletes [21]. Consuming brown sugar before exercise can help increase endurance athletes [22, 23]. Brown sugar also with a dose of 80 grams and dissolved in $250 \mathrm{ml}$ of water and then consumed 30 minutes before exercising can help improve endurance muscle athletes [24].

The average nutritional status of PPLP athletes in South Sulawesi in 2019 is based on percent body fat in the normal category. The average level of adequacy of macro nutrition in South Sulawesi PPLP athletes in 2019 per day, for carbohydrates in the less category, protein in the less category, and fat in the normal category. The average energy adequacy level of PPLP South Sulawesi athletes in 2019 per day is in the very poor category [25].

Researchers hope that the provision of palm sugar can be a natural supplement that can help improve the endurance of soccer players so that with good endurance can improve the performance of soccer players who are in SKO GOR Sudiang. This study aims to look at the effect of giving palm sugar water to the endurance of V02Max, endurance of the abdominal muscles as well as the energy intake of soccer players in the special sports school of GOR Sudiang Makassar.

\section{METHODS}

This type of research used in this study is an experimental study with a Pre-Experimental research design. The research design model is a one-group pretest-posttest. The location of this research will be carried out in the SORGANG GOR sportsman special school in Makassar. The population in this study were all students of the football sports branch in the SORGOR GOR sporting school in Makassar who had 35 people based on the results of researcher observation and the results of talks with soccer coaches in the study location. From the results of determining the inclusion and exclusion criteria, the samples obtained in this study were 30 soccer athletes because 5 samples took the PSM Makassar U16 selection.

The tools and materials used in this study will be divided as follows: (1) The manufacture of brown sugar water includes lion star brand food scales, measuring cups, medium-sized plastic cups, cooking pans, food waste filters, cutting knives, medium-size flasks, bucket. The ingredients used are palm sugar, gallon water. (2) Measuring endurance, the tools used are one med brand weight scales, height gauges (microtoise), duct tape, scissors, running track with a 
distance of 400 meters (tracks), stopwatch. The material used is a blank test, pen, or pencil. (3) Looking at energy intake includes: food photo book to facilitate the subject to remember food that has been eaten in $1 \times 24$ hours. The material used is food recall $1 \times 24$ hours, pens, or pencils.

In this study the data obtained from the results of tests and measurements in doing sports in accordance with the guidelines book and exercise measurements [5]. The results of the data are then processed using SPSS 21 for Windows software program to see the effect of supplying palm sugar water on VO2Max endurance, endurance of abdominal muscles, before conducting the test the results of the data must be tested for normality first, because the scale in this study is a ratio scale.

\section{RESULTS}

Descriptive analysis is intended to get an overview of research data, numerical data if we test for normality, normally distributed ( $\mathrm{p}$-value $=>0.05$ ) we present the data in the form (mean $\pm \mathrm{SD}$ ), if the data are not normally distributed we present it in the form of a median (min; max). Pre-post test, normally distributed data $\rightarrow$ paired t-test, if not normally distributed $\rightarrow$ Wilcoxon Signed Ranks Test.

\section{Descriptive Analysis of Subjects}

Table-1: Descriptive Statistics of the Subject

\begin{tabular}{|l|l|l|}
\hline \multicolumn{1}{|c|}{ Characteristics (n=30) } & \multicolumn{1}{|c|}{ mean } & SD \\
\hline Age $($ Years) & 16,5 & 0,50 \\
Weight $(\mathrm{kg})$ & 54,6 & 9,21 \\
Height $(\mathrm{cm})$ & 165,5 & 5,79 \\
Body mass index (Weight/Height') & 19,8 & 2,54 \\
\hline \multicolumn{3}{c}{ Primary data source, 2020. } \\
\hline
\end{tabular}

The data in Table-1 shows the mean or average value of the sample characteristics starting from age, which shows 16.5 , which means the average sample is 16 years old with a standard deviation of 0.50 , for the sample weight obtained 54.6 which means the average sample has a bodyweight of $54 \mathrm{~kg}$ with a standard deviation of 9.21 , for the height of the sample obtained an average value of 165.5 which means the average sample has a height of $165 \mathrm{~cm}$ with a standard deviation of 5.79 and BMI the sample has obtained a value of
19.8 which means that the average sample has a BMI of 19.8 shows that the sample is at a state of ideal body weight or normal with a standard deviation of 2.54 .

This data illustrates that the condition of athletes in SKO (Sport School) GOR (Sport Building) Sudiang has good body condition or it can be said that the athletes' body weight is in the good category.

\section{Energy Intake Analysis}

Table-2: Analysis of Energy Intake

\begin{tabular}{|l|l|l|l|l|}
\hline Characteristics $(\mathbf{n}=30)$ & Median & Minimum & Maximum & P-Value \\
\hline Athlete Energy Needs per day & 3489,76 & 3050,96 & 4777,40 & \\
\hline Pre-Test & 2132,35 & 1162,10 & 3888,90 & \\
\hline Post-Test day 8 of the Research & 2726,06 & 1150,90 & 4178,60 & 0,002 \\
\hline Post-Test day 15 of the research & 2881,57 & 1726,60 & 4019,80 & 0,000 \\
\hline
\end{tabular}

Primary data source, 2020.

The data in Table-2 shows the median, minimum, maximum, and $\mathrm{P}$ values that follow the study. The average energy intake that athletes must meet in a day is a median of 3489.76 in a day, the average pre-test energy intake of a median is 2132.35 a day, this shows that the average athlete's energy intake that follows the research is in the less category From the amount of energy intake they should consume, the posttest energy intake on day 8 of the study averaged 2726.06 in this day also showed that the average amount of energy intake of athletes after the intervention was still in the category of less than the amount of energy intake should have been but if
Compared with the athlete's pre-test score, this value has increased and the post-test 15 days of research a median average of 2881.57. This value illustrates that the average athlete's energy intake is still in the category of less than the energy consumption they should consume, thus it can be concluded that the amount of athlete's energy intake in SKO (Sport School) GOR (Sport Building) Sudiang has a significant increase based on indigo $\mathrm{P}=0,002$ in the 8th-day post-test of the study and the value of $\mathrm{P}=0,000$ in the 15th-day post-test of the study but still in the category of less than the amount of energy intake that should be in a day. 


\section{V02Max Endurance Analysis}

Table-3: V02Max Endurance Analysis

\begin{tabular}{|l|l|l|l|l|}
\hline V02Max Characteristics $(\mathbf{n = 3 0})$ & Median & Minimum & Maximum & P-Value \\
\hline Pre-Test & 43,48 & 34,50 & 47,10 & \\
\hline Post-Test Research day 8 & 46,69 & 39,00 & 50,50 & 0,000 \\
\hline Post-Test Research day 15 & 50,34 & 45 & 53 & 0,000 \\
\hline
\end{tabular}

Primary data source, 2020.

The data in Table-3 shows the median, minimum, maximum, and $\mathrm{P}$-value of the sample that took part in the study. The average V02 maximal pretest durability of the median was 43.48 in the sufficient V02 Max durability category, on the post-test day 8 of the study obtained the median average value is 46.69 in the good category, on the post-test day 15 the median average is 50.3 in the good category this value illustrates that the average endurance value of V02Max athletes has increased before and after the intervention where before the intervention the sample is in the sufficient category and after the intervention, the V02Max value of the sample is in the good category is also supported by the results of data analysis where the value of $\mathrm{P}=0,000$ on the post-test day 8 of the study and the same results were also obtained on the post-test day 15 study with a value of $\mathrm{P}=0,000$ this value indicates that this study was successful and the results were significant.

\section{Stomach/Abdominal Muscle Endurance Analysis}

Table-4: Analysis of Abdominal Muscle Endurance

\begin{tabular}{|l|l|l|l|l|}
\hline Abdominal Muscle Endurance Characteristics (n=30) & Median & Minimum & Maximum & P-Value \\
\hline Pre-Test & 55,80 & 37,00 & 73,00 & \\
\hline Post-Test Research day 8 & 59,76 & 38,00 & 77,00 & 0,000 \\
\hline Post-Test Research day 15 & 65,26 & 45,00 & 82,00 & 0,000 \\
\hline
\end{tabular}

Primary data source 2020

The data in Table-4 shows the median, minimum, maximum, and $\mathrm{P}$-value of the sample that took part in the study. The average abdominal endurance of the pre-test of the median was 55.80 in the category of the endurance of the abdominal muscles very well, on the post-test day to 8 studies obtained an average median value of 59.76 is in the excellent category, on the post-test day 15 the median average is 65.26 in the excellent category, this value illustrates that the average value of endurance Athlete's abdominal muscles have increased before and after the intervention, this value is supported by the results of data analysis in which the value of $\mathrm{P}=0,000$ on the 8thday post-test study and the same results were also obtained on the 15th-day post-test of the study with a value of $P=0,000$ this is a sign that this research was successful and the results are significant.

\section{DISCUSSION}

Consuming palm sugar water has an influence on energy intake after an intervention in the athlete's special soccer school athlete GOR Sudiang Makassar. Researchers found that consuming palm sugar water can provide additional energy intake to athletes whose energy intake is less than the energy intake they should meet in a day so that it can help athletes get additional energy.

The average athlete's energy needs in the research location on the 8th day is 2726.06 and on the 15 th day of the study 2881.57 there is an increase but it is still very far from the average adequacy rate of the athlete's energy intake should be equal to 3489.76 . can not be separated from the conditions of athletes who were there, by staying boarding-lodging they eat food according to what they like and adjust it to the amount of money they have, for the administrators at this research site the researchers hope that management will pay attention to the athletes' food, in order to get maximum performance

According to palm sugar contains Riboflavin which helps the formation of red blood cells, produces antibodies, along with enzymes also produce the energy needed by the human body, some vitamin A improves the mucous membranes in the digestive tract, inhibits cell damage during the process of energy production, improves the working system of tissues and the body's digestive tract, Thiamine Substance which functions as a coenzyme in energy metabolism, strengthens the nervous system and muscles, and helps the body and uses protein [26 17].

Niacin substances that function as coenzymes in glucose, fat and alcohol metabolism, glucose, fat and alcohol, help skin health, nervous system and digestive system, reduce LDL cholesterol levels and improve brain function. Vitamin B6 and others that are useful for protein and carbohydrate metabolism help in the production of red blood cells, as well as helping the body's immune system.

In this study researchers gave palm sugar water during the intervention process was given as 
much as 50 grams dissolved in $250 \mathrm{ml}$ water and drink 30 minutes before exercising in the afternoon for 14 consecutive days.

Consuming palm sugar water has an influence on the endurance of V02Max after an intervention in a soccer athlete in a special school for sportsman GOR (Sport Building) Sudiang Makassar. This research found that by consuming palm sugar water 30 minutes before exercising or doing exercises for one week in a row can increase the endurance of V02Max athletes, and if consumed for two consecutive weeks will increasingly make endurance V02Max athletes increase, consuming palm sugar water before exercising can make the athlete's body not get tired quickly when doing sports activities.

Athletes who drink palm sugar water before doing sports experience an increase in endurance V02Max but an increase in endurance V02Max for each athlete is different, drinking palm sugar water before testing a soccer game can make the body not easily feel tired so athletes can display performance the best in playing football is based on the results of tests on the field by researchers where children of South Sulawesi SKO were given 30 red sugar water drinks before conducting a trial match.

The first match on Saturday, March 14, 2020, at 14.30 at the Barombong Stadium, at that time the children of SKO (Special Sports School) of South Sulawesi against Bajeng United, South Sulawesi SKO children appeared in excellent condition, the SKO players in South Sulawesi controlled the ball from the beginning of the game until the end. the match, the players feel they get extra energy after consuming palm sugar water before competing for the recognition of several players to researchers, the match was won by SKO Sulsel with a score of 2-0.

The second trial match precisely in the Soppeng area Wednesday 18 March 2020 at 16.00 on the Takalalla Wisdom Field, SKO Sulsel against Patriot sewo, before the players took part in the competition the researchers gave a palm sugar drink 30 minutes before conducting a trial of a soccer match, the players feeling fresh body condition and when doing sports do not get tired quickly so that athletes can display their best performance the results of the competition were won by SKO Sulsel with a score of 3-2.

The third match was to be exact on Thursday 19 March 2020 at 16.00 in the Takalalla field in South Sulawesi SKO Soppeng area against SSB (Football school) son of Mario. the beginning to the end of the match and the match results won by SKO Sulsel with a score of 2-1.

The results of this study are based on Table 4.3 Analysis of endurance v02max pre-test median average is 43.48 are in the category of endurance V02Max enough, on the post-test day 8 the study obtained the median average value is 46.69 are in the good category, on the 15th-day post-test study, the median average was 50.34 in the good category. This value illustrates that the average endurance value of V02Max athletes has increased before and after the intervention.

This research is in line with previous studies, according to [18] in a study that has done the administration of brown sugar with a dose of 21 grams in $250 \mathrm{ml}$ of water carried out 3 times a week and for 6 weeks on athletes can increase endurance athletes when doing sports.

Not in line with research [19] in his research, the provision of one week of brown sugar to athletes had no effect on endurance but brown sugar was able to suppress lactic acid levels in the body, because in this study researchers within one week had positive results that brown sugar water could increase the endurance of V02Max.

In line with [21] Consuming 50 grams of brown sugar for 12 days before doing sports activities can increase endurance athletes. Consuming brown sugar before exercise can help increase endurance athletes [22, 23]. In palm sugar water one of the ingredients is glucose where glucose is used as an energy source when doing sports by giving glucose before exercise can increase the endurance of V02Max in research [27].

The research results and findings found by researchers are in line with the theory in the book [6] concerning nutrition and exercise, where the energy obtained by the body is divided into two namely the anaerobic energy system (without the aid of oxygen) and the aerobic energy system (with the help of oxygen). Anaerobic energy systems are divided into two namely the alactic anaerobic system (does not produce lactate) and the lactic anaerobic system (produces lactate).

In this alactic energy system is an energy system that is ready to use comes from ATP and PC that are in the muscles, but this energy can only be used in a very short time of 6-8 seconds, sports that normally use this energy system include running $100 \mathrm{~m}$, swimming $25 \mathrm{~m}$, and weightlifting. If exercise continues to eat this energy will be reduced, so that the energy used is obtained again from glycogen in the muscles and glucose in the blood through the glycolysis process.

This process produces energy and lactic acid, almost all sport pins use this energy system. Lowintensity exercise gets energy from the aerobic energy system (with the help of oxygen) that comes from the process of breaking down carbohydrates, fats, and 
proteins. Aerobic and anaerobic energy systems work simultaneously according to energy requirements.

The use of oxygen (V02Max) in the body with an efficient can be a source of energy that can meet the needs of the body athlete in doing sports and achieving performance. The longer and harder the exercise the athlete does, the greater the amount of oxygen used to produce energy. The body has different and limited abilities in obtaining oxygen.

In this study the researcher gave an explanation to the sample regarding the conduct of the study, samples that met the inclusion criteria would participate in the series of studies. In measuring the endurance of V02max, it is carried out with a 15-minute bales test method. The test is carried out three times in two weeks, this test looks at how many laps or running distance each athlete who took the test. The pre-test and post-test scores in this study are then entered into the test data and sports measurements, which after that will be entered again in the SPSS program to test the validity of the research results obtained by researchers in the field. The intervention was given a day after the pre-test was conducted by the researcher. The intervention is given 30 minutes before the sample exercises in the afternoon, for 14 consecutive days.

Consuming palm sugar water has an influence on the endurance of the abdominal muscles after an intervention in a soccer athlete at a special school for sportsman GOR Sudiang Makassar. Researchers found in this study that samples that routinely drink palm sugar 30 minutes before doing exercise for one week can increase the endurance of the abdominal muscles, if consumed for 14 consecutive days then the endurance of the abdominal muscles will increase.

This research is in line with research [24] who saw the effect of palm sugar on muscle endurance, wherein the implementation of this study a sample of 18 trained athletes were given a muscle endurance test that included push-ups, sit-ups and squat jump tests until they felt tired, the test was carried out on days that were different, the sample is divided into 3 groups, the first group gets the intervention of red sugar water drink with a dose of 80 grams dissolved in $250 \mathrm{ml}$ water, the second group gets the intervention to drink sugar water sugar with a dose of 75 grams dissolved in $250 \mathrm{ml}$ water, and the group control get regular mineral water drinks with $250 \mathrm{ml}$.

The day before the pre-test and post-test implementation of the samples were told to fast so that the samples were in the same condition, the results obtained were evident in the intervention group with palm sugar increased muscle endurance increased when compared to the group that only drank sugar water sand and groups that drink ordinary mineral water.
The research results and findings found by researchers are in line with the theory in the book [6] concerning nutrition and exercise, where the energy obtained by the body is divided into two namely the anaerobic energy system (without the aid of oxygen) and the aerobic energy system (with the help of oxygen). Anaerobic energy systems are divided into two namely the alactic anaerobic system (does not produce lactate) and the lactic anaerobic system (produces lactate).

In this alactic energy system is an energy system that is ready to use comes from ATP and PC that are in the muscles, but this energy can only be used in a very short time of 6-8 seconds, sports that normally use this energy system include running $100 \mathrm{~m}$, renag 25 $\mathrm{m}$, and weightlifting. If exercise continues to eat this energy will be reduced, so that the energy used is obtained again from glycogen in the muscles and glucose in the blood through the glycolysis process.

This process produces energy and lactic acid, almost all sport pins use this energy system. Lowintensity exercise gets energy from the aerobic energy system (with the help of oxygen) that comes from the process of breaking down carbohydrates, fats, and proteins. Aerobic and anaerobic energy systems work simultaneously according to energy requirements.

The use of oxygen (V02Max) in the body with an efficient can be a source of energy that can meet the needs of the athlete body in doing sports and achieving performance. The longer and harder the exercise the athlete does, the greater the amount of oxygen used to produce energy. The body has different and limited abilities in obtaining oxygen.

In this study the researcher gave an explanation to the sample regarding the conduct of the study, samples that met the inclusion criteria would participate in the series of studies. In measuring the endurance of the abdominal muscles carried out by the method of sit-up test 1 minute, the test is carried out three times in two weeks, this test looks at how many laps or running distance each athlete who took the test. The pre-test and post-test scores in this study were then entered into the sports test and measurement data, which after that will be entered again in the SPSS program to test the validity of the research results obtained by researchers in the field. The intervention was given a day after the implementation of the pre-test by the researcher. The intervention is given 30 minutes before the sample exercises in the afternoon, for 14 consecutive days.

\section{CONCLUSION}

Consuming palm sugar water has an effect on energy intake after the intervention in the athlete's special soccer school athlete GOR Sudiang Makassar were the post-test score on day $8(\mathrm{p}=0.002)$ and post 
tets day $15(\mathrm{p}=0.000)$. Consuming palm sugar water has an influence on the endurance of V02Max after intervention in soccer athletes at the GOR Sudiang Makassar sports school were the post-test score on day $8(\mathrm{p}=0,000)$ and post-day $15(\mathrm{p}=0,000)$. Consuming palm sugar water has an effect on the endurance of the abdominal muscles after an intervention in soccer athletes at the GOR Sudiang Makassar sportsman school were the post-test score on day $8(\mathrm{p}=0,000)$ and post-test day $15(\mathrm{p}=0,000)$.

\section{REFERENCES}

1. Rahmad, H. A. (2016). Pengaruh Penerapan Daya Tahan Kardiovaskuler VO2MAX Dalam Permainan Sepak Bola PS Bina Utama. Journal of Teaching and Learning, 1(2): 1-10.

2. Prasetya, Y. Y., \& Hariadi, I. (2018). Profil Kondisi Fisik Atlet Persatuan Sepak Bola Malang U-17 (Persema). Indonesia Performance Journal, 2(2), 105-110.

3. Ilissaputra, D. A., \& Suharjana, S. (2016). Pengaruh metode latihan dan VO2 Max terhadap dasar sepak bola. Jurnal Keolahragaan, 4(2), 164-174.

4. Artanty, A., \& Lufthansa, L. (2017). Pengaruh latihan lari 15 menit terhadap kemampuan VO2 max. Jendela Olahraga, 2(2).

5. Halim, N. I. (2011). Tes dan pengukuran kesegaran jasmani. Makassar: Badan Penerbit UNM.

6. Syafrizar., \& Welis, W. (2016) Gizi Olahraga, ILMU GIZI :Teori \& Aplikasi. Malang: Wineka Media.

7. Pertiwi, A. B., \& Murbawani, E. A. (2012). Pengaruh Asupan Makan (Energi, Karbohidrat, Protein dan Lemak) terhadap Daya Tahan Jantung Paru (VO2 Maks) Atlet Sepak Bola. Doctoral dissertation, Diponegoro University.

8. García-Rovés, P. M., García-Zapico, P., Patterson, Á. M., \& Iglesias-Gutiérrez, E. (2014). Nutrient intake and food habits of soccer players: analyzing the correlates of eating practice. Nutrients, 6(7), 26972717.

9. Tanuwijaya, J. (2013). Karsono. The effects of crospovidone and croscarmellose sodium as superdisintegrants on the characteristics of piroxicam nanoparticles ODT (orally disintegrating tablet). Int $J$ PharmTech Res, 5(4), 1590-1597.

10. Kord, G. (2014). Comparison of White Corpuscles' Components between Two Levels of Body Fitness of Athletes and Non-athletes'(VO2MAX) among Boys' High School Students. Donnish Journal of Educational Research and Reviews, 1(1), 007-011.

11. Mappanyuki, A. A., Ichsani, I., \& Ihsan, I. (2019). Perbandingan pemberian karbohidrat sederhana dan karbohidrat kompleks terhadap daya tahan kardiovaskular pada pemain sepak bola Tim SSB Taeng. In Seminar Nasional LP2M UNM.

12. Syamsul. (2019). Peranan Buah Pisang Ambon Terhadap Daya Tahan Jantung Paru (Cardiorespiratory Endurance) Atlet Karate. Jurnal Riset Kesehatan Poltekes kemenkes Bandung, 11(1):
$148-156$.

13. Sari. (2018). Pengaruh Minum Kopi Terhadap Kekuatan Otot Atlet Sepak Bola Pusamania Borneo Football Club Di Samarinda. Fakultas kesehtan masyarakat dan farmasi Universitas Muhammadiyah Kalimantan Timur.

14. Habibi, A. I., \& Artanty, A. (2019, October). Perbandingan Kemampuan Daya Tahan Otot Lengan Setelah Aktivitas Eksentrik Dengan Mengkonsusmsi Glukosa Dan Kopi. In Prosiding Seminar Nasional Iptek Olahraga (Senalog), 2(1).

15. Usman, A., \& Muriyati. (2015). The Effect of Caffeine on VO2Max Athletes Ability. International Journal of Sciences, 4531(1): 231.

16. Rahmat, R., \& Welis, W. (2018). Pengaruh Pemberian Sari Kurma Terhadap Kemampuan Daya Tahan Tim Sepakbola SMAN 1 Banuhampu Kabupaten Agam. Jurnal Stamina, 1(1), 235-244.

17. Heryani, H. (2016). Keutamaan Gula Aren dan Strategi Pengembangan Produk. ULM.

18. Tanuwijaya, R. R., Kristiyanto, A., \& Doewes, M. (2017). Pengaruh Pemberian Air Gula Merah Terhadap Kebugaran Jasmani. Jurnal Gizi, 6(2).

19. Abdurahman, M. N., Ray, H. R. D., \& Ruhayati, Y. (2018). Potensi Gula Merah dalam Meningkatkan Penampilan Olahraga. Jurnal Terapan Ilmu Keolahragaan, 3(1), 24-29.

20. Samudera, I. P. P., \& Ashadi, K. (2019). Perbandingan Beragam Jenis Air Minum Terhadap Status Hidrasi Melalui Aktivitas Fisik 5000 Meter. Multilateral Jurnal Pendidikan Jasmani dan Olahraga, 18(1).

21. Hasibuan, R. H. (2013). Kontribusi energi 50 gram gula merah terhadap daya tahan pada pemain sepak bola Sejati Pratama Medan. Jurnal Ilmu Keolahragaan, 12(1), 35-40.

22. Akbar, M. F., Wahyudin., \& Arimbi (2016). Pengaruh pemberian gula merah sebelum latihan terhadap daya tahan pada atlet sepakbola sma negeri keberbakatan provinsi sulawesi selatan. Doctoral dissertation, Universitas Negeri Makassar.

23. Eva, A. (2019). Pengaruh Pemberian Air Gula Merah Terhadap Daya Tahan Kardiovaskular Pada Atlet Bola Volly SMA Negri 26 Bone. Doctoral dissertation, Universitas Negeri Makassar.

24. Alawi, C. M., \& Ray, H. R. D. (2019). Pengaruh Mengkonsumsi Gula Aren (Arenga pinnata) Sebelum Olahraga Terhadap Daya Tahan Otot. Jurnal Ilmu Faal Olahraga Indonesia, 1(1), 20-25.

25. Tahir, A. F., Basith, I., \& Arimbi. (2019). Survei Status Gizi Atlet PPLP Provinsi sulawesi selatan: 19.

26. Sintia. (2011). Gula Pasir Versus Gula Aren. Bandung: Radar Bandung.

27. Arimbi, A., Usman, A., Arfanda, P. E., Alamsyah, N. F., \& Safaruddin, S. (2019). Efektivitas Glukosa dan Sukrosa Terhadap Peak Expiratory Flow Rate (PEFR) dan Daya Tahan Kardiovaskular. In Seminar Nasional LP2M UNM. 